\title{
Hatching, Growth and Feed Preference of Hatchlings of Volagalea cochlidium (Linnaeus, 1758)
}

Laxmilatha P. $^{1}$, Pattnaik P. ${ }^{2}$, Nageswara Rao T. ${ }^{2}$, Prasada Rao M. ${ }^{2}$, Padmaja Rani S. ${ }^{2}$

1 Central Marine Fisheries Research Institute, P.B. No. 1603, Ernakulam North P.O. Cochin 682 018, Kerala, INDIA

2 Visakhapatnam Regional Centre of Central Marine Fisheries Research Institute, Ocean View Layout, Pandurangapuram, Visakhapatnam 530003, Andhra Pradesh, INDIA.

$\varnothing$ Corresponding author Email: laxmil@yahoo.com, laxmilatha@cmfri.org.in

International Journal of Aquaculture, 2015, Vol.5, No.19 doi: 10.5376/ija.2015.05.0019

Received: 11 May, 2015

Accepted: 23 Jun., 2015

Published: 08 Jul., 2015

Copyright () 2015 Laxmilatha et al., This is an open access article published under the terms of the Creative Commons Attribution License, which permits unrestricted use, distribution, and reproduction in any medium, provided the original work is properly cited.

Preferred citation for this article:

Laxmilatha P., Pattnaik P., Nageswara Rao T., Prasada Rao M. and Padmaja Rani S., 2015, Hatching, Growth and Feed Preference of Hatchlings of Volagalea cochlidium (Linnaeus, 1758), International Journal of Aquaculture, 5(19): 1-8

\begin{abstract}
The hatching, growth and feed preference of hatchlings of the whelk Volagalea cochlidium (Linnaeus, 1758) (synonymous with Hemifusus pugilinus) under laboratory conditions is described. The egg capsules were semi-transparent; light yellow in color and trapezoidal in shape. Each capsule had 75-80 embryos. The length of the capsules along with the holdfast ranged from 14.98 to $23.26 \mathrm{~mm}$. The hatchlings crawled out of the capsules after 30 days of incubation at $28-30^{\circ} \mathrm{C}$. The mean shell length of the newly hatched out hatchling was $1.364 \pm 0.009$ and mean width $0.096 \pm 0.011 \mathrm{~mm}$. The hatchlings were fed five different diets and reared for 62 days to compare the effects on growth and survival. The most preferred feed was mussel meat, followed by clam feed, shrimp meat. Higher growth rates were recorded for those fed with mussel meat and highest cumulative mortality occurred in those fed with oyster meat. The whelk is in high demand for its shell and operculum and is exploited indiscriminately. This study indicates its potential for aquaculture and replenishment of wild stock through stock enhancement programs using hatchery produced juveniles of the whelk.
\end{abstract}

Keywords Volagalea cochlidium; whelk; aquaculture; growth and feed; hatchlings

\section{Introduction}

The whelk, Volagalea cochlidium (Linnaeus, 1758), (synonymous with Hemifusus pugilinus) is a marine prosobranch gastropod distributed all along the southeast coast of India and inhabits sandy mud substratum at depth of 3 to over $30 \mathrm{~m}$. Shells are ornamental and are in great demand in the shell craft and lime industries. The operculum of $V$ cochlidium is used in Unani medicine and priced at INR 0.30 per piece (Narasimham et al., 1984). They are landed in shrimp trawlers, however mostly they are fished by handpicking in the intertidal muddy flats. The meat is edible and is consumed in Japan and India (Kira, 1962; Sundaram, 1974).

Most marine gastropods reproduce through copulation and lay eggs encapsulated in tough, multi layered capsules or gelatinous masses attached to hard substrates with a hold fast (Natarajan, 1957; Hawkins and Hutchinson, 1988; Rawlings, 1999). However, large variations occur in terms of capsule shape, size, and number as well as in the mode of larval development among different species (Spight 1976, Yamamoto 1997).
For instance, development in the marine prososprach Nucella lapillus is intra capsular (Pechenek et al., 1984). In the spotted babylon Babylonia areolata and the spiral babylon $B$ spirata, the hatchlings are planktonic and become benthic after metamorphosis (Chaitanawisuti and Kritsanapuntu, 1997; Sreejaya et al., 2004); in other species metamorphosis occurs prior to hatching (Collin, 2003., Gallardo and Penchaszadeh 2001, Morton 1986a, Wilson, 1985, Hamada1974, Xu et al., 2006).

Understanding feeding, feed requirements and the impact of diets on growth and survival will facilitate the culture of whelks. However, limited information on these aspects is available. Effects of different diets on growth and survival of $B$ undatum (Nasution and Roberts, 2004), impact of diet on the growth and proximate composition of juvenile whelks Dicathais orbita (Woodcock and Benkendorff, 2008); nutritive value of Chicoreus ramosus (Xavier and Ayyakkannu, 1992) and effects of starvation on larval growth and survival of Babylonia formosae (Zheng et al., 2005) 
have been reported.

Very limited information is available on the breeding and seed production of the genus Volagalea. Reproduction, juvenile growth, consumption, effects of starvation, prey preference and capture in Hemifusus tuba has been described by Morton (1986 a, b). Juvenile growth and effects of cannibalism in $H$ tuba also has been described (Morton 1987). Effect of temperature, sediment and food on hatching and growth of juveniles of Hemifusus tuba has been studied by Lu et al. (2009). Growth and feeding of $H$ ternatanus in early crawling stage has been described by Hamada (1974). Breeding ecological conditions of $H$ ternatanus has been described by $\mathrm{Zu}$ et al. (2006). Hatching growth and dietary preferences in Hemifusus ternatus has been detailed by Tang et al. (2012). Anandakumar et al. (1986) evaluated the biochemical constituents of $H$ pugilinus. Ultra structure of the egg capsule of Chicoreus virgineus and $H$ pugilinus has been studied by Kaviarasan et al. (2011). Antipathogenic activity $H$ pugilinus from south east coast of India has been reported by Dhinakaran et al. (2011). Sekar et al. (2012) described the nutritive profiles of different size groups and body parts of $H$ pugilinus.

The present research was an attempt to maintain and breed $V$ cochlidium under captivity and develop hatchling rearing techniques and understand feed preferences of hatchlings. The study was conducted to assess the potential of $V$ cochlidium as a future mariculture species and provide basic information on hatchling production and rearing. The prospects for replenishing / re seeding wild stocks with hatchery produced juveniles are also discussed.

\section{Materials and Methods}

\subsection{Broodstock maintenance, laying of egg capsules and hatching}

Broodstock of Volagalea cochlidium were collected from the Kakinada Bay of Andhra Pradesh and transported to the Mariculture hatchery of Visakhapatnam Regional Centre of Central Marine Fisheries Research Institute. They were maintained in 1 ton fibre glass tanks in filtered sea water of 30-32 \%o salinity. They were fed fresh or frozen meat of bivalves (Perna viridis, Meretrix casta) and squids. After laying of the egg capsules by the whelk, the number of egg capsules were counted. The shell length, shell width and the length of the apical aperture of the egg capsules were recorded using digital Vernier calipers. The number of eggs / developing embryos inside each capsule was counted using a compound microscope. On hatching, the shell length and width of the hatchlings were also recorded.

\subsection{Feeding experiment}

The hatchlings were transferred after three weeks, to glass tanks of $5 \mathrm{Lt}$ capacity. They were fed with five different meats viz. Meretrix meretrix (fresh clam meat), Perna viridis (fresh mussel meat), Crassostrea madrasensis (frozen oyster meat), Stolephorus sp. (frozen fish meat) and Metapenaeus dobsoni (frozen shrimp meat) for a period of 62 days. The hatchlings were reared in $30-32 \mathrm{ppt}$ salinity and $28-30^{\circ} \mathrm{C}$. For each treatment two replicates were set along with control in which no feed was provided. The hatchlings were fed in the morning and excess feed was siphoned out in the evening. The acceptance, food preference and growth were monitored. The shell length, shell width and total weight were recorded at weekly intervals. Mortality was also recorded and the dead individuals were removed to avoid cannibalism and maintain quality of water.

\subsection{Analysis}

The Specific Growth Rate (SGR \%) for shell length and shell width of the hatchlings fed on different diets were calculated from

$S G R \%=\left[\left(\ln L_{2}-\ln L_{1}\right) /\left(T_{2}-T_{1}\right)\right] * 100$

where, $L_{1}$ and $L_{2}$ are mean shell length and mean shell width at times $T_{1}$ and $T_{2}$ in days.

All treatments were presented as means and standard deviation. ANOVA was performed for growth data using SPSS version 16 statistical software. When a significant effect (0.05) of diets on growth was found, a multiple comparison (Tukey HSD and Duncan's) was conducted to compare the significant differences among feeding treatments.

\section{Results}

\subsection{Laying of egg capsules}

Female whelk of $80.13 \mathrm{~mm}(\mathrm{SH}), 41.4 \mathrm{~mm}(\mathrm{SW})$ and total weight $53.04 \mathrm{~g}$ (Figure. 1), laid a string of $40 \mathrm{egg}$ capsules on 16 October 2012 (Figure 2, 3). A second string of 37 capsules were laid on 11 November 2012. Egg capsules (38-40 numbers) were continued to be laid at almost monthly internals. The capsules were 


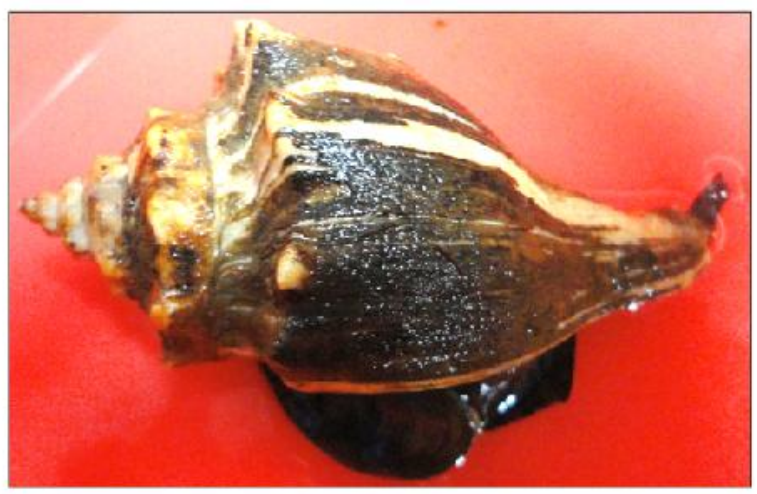

Figure 1 Female whelk Volagalea cochlidium

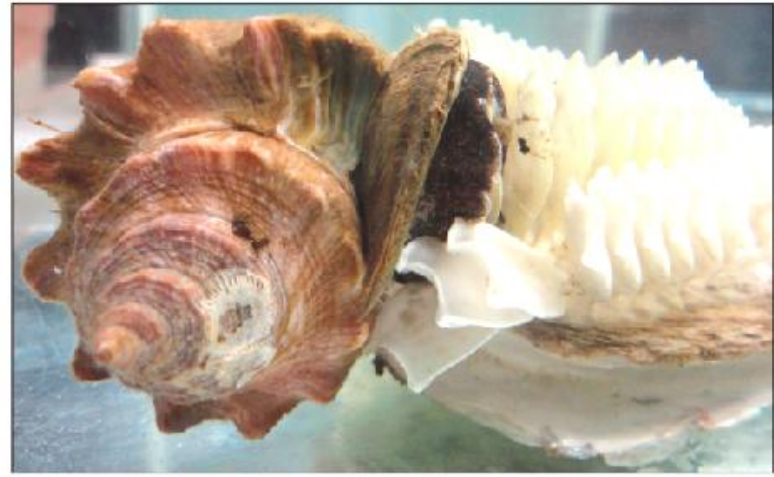

Figure 2 Female whelk $V$ cochlidium laying egg capsules

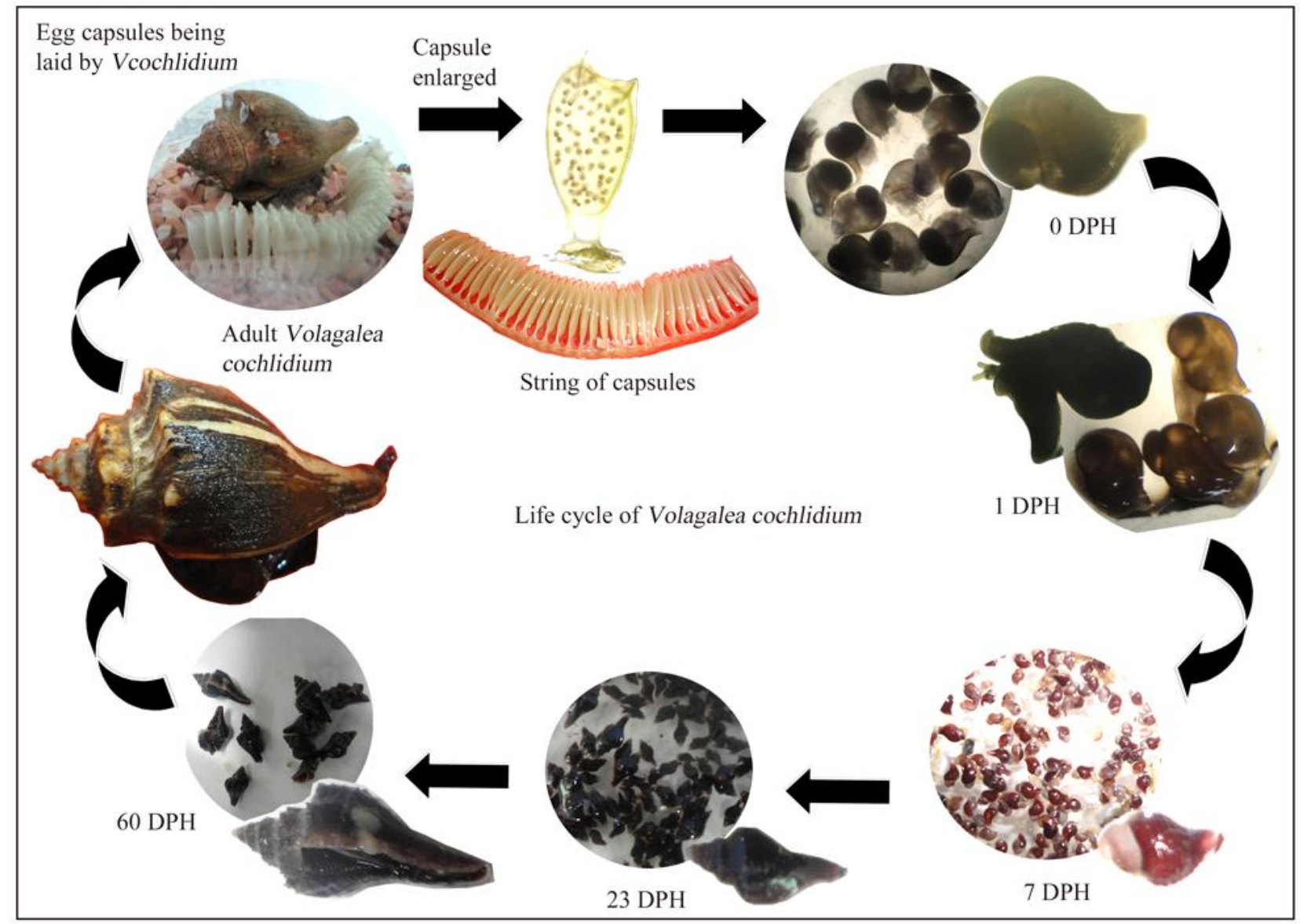

Figure 3 Life cycle of $V$ cochlidium

held together by a common holdfast and attached to the substratum by the peduncle (Figure 3). Development was intra-capsular and the hatchlings were released from the capsules on the $28^{\text {th }}$ to $30^{\text {th }}$ day of incubation in the first spawning and $30-33^{\text {rd }}$ day in the second, indicating that temperature influences hatching. The prevailing temperature was $28-30^{\circ} \mathrm{C}$ during the first incubation while it was $26-28^{\circ} \mathrm{C}$ in the second case. A total number of 3200 and 2900 hatchlings were released from the first and second spawning respectively. The hatching rate was $85 \%$. The hatchlings were fed fresh meat of bivalves (Perna viridis, Meretrix casta) as well as frozen squid meat.

\subsection{Capsules}

The capsules were semi-transparent; light yellow in color and almost trapezoidal in shape. Each capsule had 75-80 embryos (Figure 3). The developing embryos 
inside the capsule were suspended in a colloidal / mucus-like substance. The length of the capsules along with the holdfast ranged from 14.98 to $23.26 \mathrm{~mm}$. The length of the capsule without the holdfast ranged from 14.04 to 19.64 . The width of the capsule ranged from 9.23 to $11.41 \mathrm{~mm}$ and the aperture of the capsule ranged from 6.42 to $8.23 \mathrm{~mm}$. The size of the capsule appeared to decrease from the first laid to last laid capsule. The mean length of the capsules was $20.72 \pm$ $1.83 \mathrm{~mm}$, mean width $10.81 \pm 0.45 \mathrm{~mm}$ and mean length of the capsule aperture $7.73 \pm 0.39 \mathrm{~mm}$.

\subsection{Hatching}

As the embryos developed within the capsule, they turned brownish-yellow in color. The capsules dehisced at the aperture on the $28-32^{\text {rd }}$ day to release the hatchlings which were exactly like the adult whelk. The hatchlings were deep red to brown in color, actively crawling on the bottom of the tanks and feeding on clam / mussel meat provided to them. The freshly hatched young whelks were also found swimming on the water surface for 2-3 days post hatching. The mean shell length of the newly hatched hatchling was $1.364 \pm 0.009$ and mean width $0.096 \pm$ $0.011 \mathrm{~mm}$. On the tenth day, the mean shell length was
$1.853 \pm 0.038 \mathrm{~mm}$ and width $0.120 \pm 0.017 \mathrm{~mm}$. On the $23^{\text {rd }}$ day post hatching, the mean shell length was $4.268 \pm 0.922$ and mean width was $2.493 \pm 0.402 \mathrm{~mm}$. The mean shell length on the $35^{\text {th }}$ day post hatching was $5.53 \pm 1.27$ and mean width $1.27 \pm 0.63 \mathrm{~mm}$ (Figure 4).

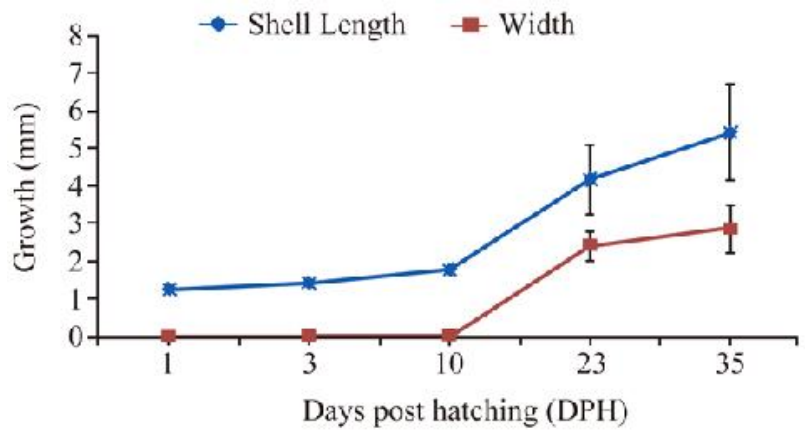

Figure 4 Growth of $V$ cochlidium hatchlings

\subsection{Feed preference and growth of hatchlings}

The hatchlings were fed with five different diets and the most favored feed was mussel meat followed by clam meat. The least preferred was oyster meat. Higher growth rate was observed in hatchlings fed with mussel meat and clam meat. The hatchlings fed with mussel meat attained a mean shell length of 16.85
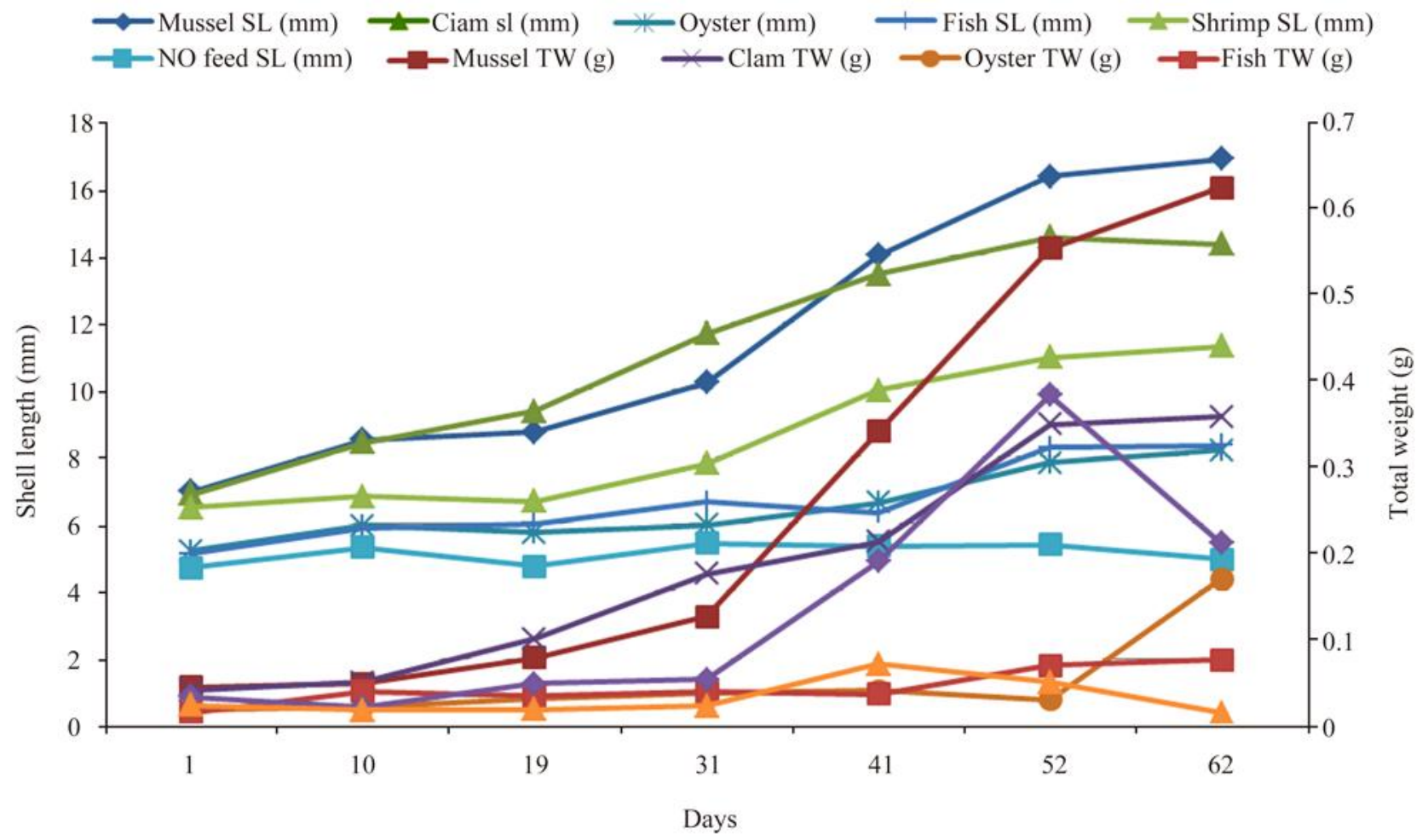

Figure 5 Growth of $V$ cochlidium hatchlings fed on different feed 
$\pm 2.69 \mathrm{~mm}$, mean shell width $8.14 \pm 1.39 \mathrm{~mm}$ and mean total weight $0.62 \pm 0.22 \mathrm{~g}$ in 62 days. The absolute growth recorded in 62 days was mean shell length of $9.9 \mathrm{~mm}$, mean shell width $4.7 \mathrm{~mm}$ and mean total weight $0.6 \mathrm{~g}$. The highest mean growth rate in terms of shell length was $0.16 \mathrm{~mm} /$ day, shell width $0.07 \mathrm{~mm} /$ day and total wet weight $0.01 \mathrm{~g} /$ day when the hatchlings were fed with mussel meat (Figure 5).

The hatchlings fed with clam meat attained a mean shell length of $14.31 \pm 2.61 \mathrm{~mm}$, mean shell width $6.61 \pm 1.43 \mathrm{~mm}$ and mean total weight $0.36 \pm 0.15 \mathrm{~g}$ in 62 days. The absolute growth recorded in 62 days was mean shell length of $7.42 \mathrm{~mm}$, mean shell width $3.05 \mathrm{~mm}$ and mean total weight $0.32 \mathrm{~g}$. The mean growth rate in terms of shell length was $0.12 \mathrm{~mm} /$ day, shell width $0.05 \mathrm{~mm} /$ day and total wet weight $0.01 \mathrm{~g}$ / day when the hatchlings were fed with clam meat (Figure 5).

The hatchlings fed with shrimp meat attained a mean shell length of $11.28 \pm 1.67 \mathrm{~mm}$, mean shell width of $4.78 \pm 1.07 \mathrm{~mm}$ and mean total weight $0.21 \pm 0.05 \mathrm{~g}$ in 62 days. The absolute growth recorded in 62 days was $4.79 \mathrm{~mm}$ (SL), $1.69 \mathrm{~mm}$ (SW) and $0.18 \mathrm{~g}$ (TW). The mean growth rate in terms of shell length was $0.08 \mathrm{~mm} /$ day, shell width $0.03 \mathrm{~mm} /$ day and total wet weight $0.001 \mathrm{~g} /$ day when the hatchlings were fed with shrimp meat (Figure 5).

The hatchlings fed with fish meat attained a mean shell length of $8.34 \pm 1.97 \mathrm{~mm}$, mean shell width 3.32 $\pm 0.92 \mathrm{~mm}$ and mean total weight. $0.08 \mathrm{~g}$ in 62 days. The absolute growth recorded in 62 days was mean shell length of $3.22 \mathrm{~mm}$, mean shell width $0.60 \mathrm{~mm}$ and mean total weight $0.06 \mathrm{~g}$. The mean growth rate in terms of shell length was $0.05 \mathrm{~mm} /$ day, shell width $0.01 \mathrm{~mm} /$ day and total wet weight $0.001 \mathrm{~g} /$ day when the hatchlings were fed with fish meat (Figure 5).

The hatchlings fed with edible oyster meat attained a mean shell length of $8.18 \pm 1.85 \mathrm{~mm}$, mean shell width $3.66 \pm 0.96 \mathrm{~mm}$ and mean total weight. $0.17 \mathrm{~g}$ in 62 days. The absolute growth recorded in 62 days was mean shell length of $3.00 \mathrm{~mm}$, mean shell width 0.80 $\mathrm{mm}$ and mean total weight $0.15 \mathrm{~g}$. The mean growth rate in terms of shell length was $0.05 \mathrm{~mm} /$ day, shell width $0.01 \mathrm{~mm} /$ day and total wet weight $0.001 \mathrm{~g} /$ day when the hatchlings were fed with oyster meat.
Significant differences were observed in terms of total shell length, shell width and total weight $(\mathrm{p}<0.05)$ within the groups fed on different diets and no feed. Multiple comparisons of the treatments showed significant differences in the rate of growth with respect to shell length, width and wet weight among the groups fed on different diets. No significant differences were observed between individuals within a group.

\subsection{Specific growth rates}

The specific growth rates of the hatchling fed with five different meat diets in terms of shell length and shell width was highest when the hatchlings were fed with mussel meat, followed by clam meat, shrimp, fish and oyster meat.

The hatchlings which were not provided with feed, interestingly survived till the end of the experiment but recorded relatively poor growth, growth rate and specific growth rates (Figure 5).

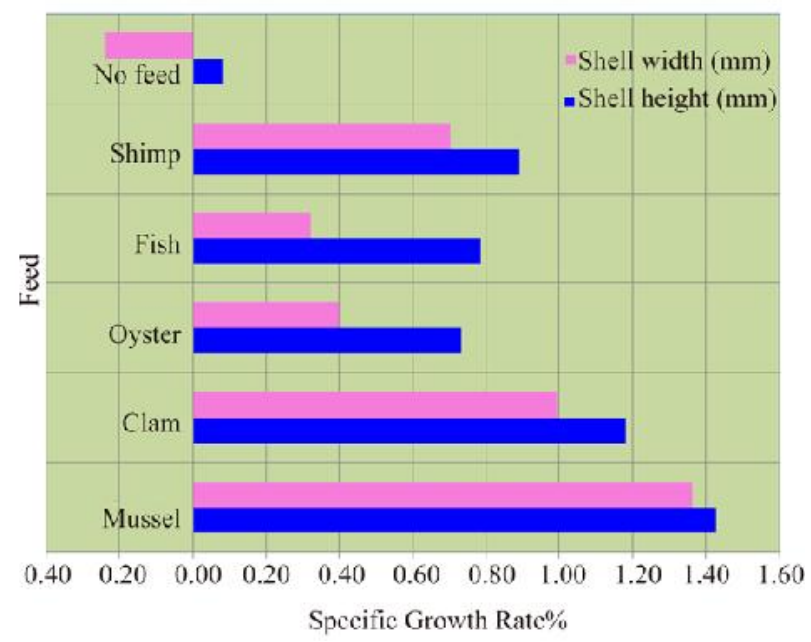

Figure 6 Specific growth rates of $V$ cochlidium hatchlings fed with 5 diets

\subsection{Survival}

Progressive mortality occurred during the course of the feeding experiment. Over $50 \%$ mortality occurred in all the experimental groups (except those fed with clam meat) by the $40^{\text {th }}$ day of the experiment. However, highest cumulative mortality of hatchlings occurred in the experimental groups for which no feed was provided. Highest cumulative survival was observed in the group fed with clam meat $(53.4 \%)$, followed by those fed with shrimp meat $(46.3 \%)$. Hatchlings fed with fish meat recorded a cumulative 
survival of $43 \%$. Although high growth was recorded in the whelk hatchlings fed with mussel meat, the cumulative survival was $38.7 \%$ only. The least survival $(16 \%)$ was in the experimental group fed with oyster meat. The water quality deteriorated rapidly and mortality was high during the fourth week of rearing $\left(40^{\text {th }}\right.$ day). The hatchlings showed least preference for oyster meat and also recorded poor shell growth as well as gain in wet weight.

\section{Discussion}

\subsection{Egg capsules and development}

The morphology of egg capsules of many prosobranch gastropods are highly variables with respect to size, shape and structure (Natarajan, 1957). This is attributed to environmental factors or geographical latitude (Natarajan, 1957; Chung et al., 2002). Most gastropods lay string of egg capsules and are attached to the substratum as reported in Buccinum undulatum (Martel et al., 1986), Ocenebra erinacea (Hawkins and Hutchinson,1988), Babylonia spirata (Shanmugaraj et al., 1994; Sreejaya et al., 2004), Chicoreus ramosus (Nugranad and Kerdpoom, 1995 ), H tuba (Lu et al., 2009), H pugilinus (Kaviarasan et al., 2011), Lambis lambis (Jagadis et al., 2012) and H ternatanus (Tang et al., 2012). The development is direct and intra-capsular and hatchlings are replicas of the adult. This is the case in $H$ ternatanus, $H$ tuba, B undulatum (Lu et al., 2009; Tang et al., 2012), where as in $B$ spirata, $B$ areolata, $C$ ramosus the development is intra capsular up to free swimming veliger stage and metamorphosis is completed externally (Shanmugaraj et al., 1994; Sreejaya et al., 2004; Chaitanawisuti, and Kritsanapuntu, 1997; Nugranad and Kerdpoom, 1995). Planktotrophic and direct development are the two types of development in most gastropods and there exists a strong latitudinal pattern in direct development (Natarajan, 1957; Wilson, 1985; Collin, 2003). Nurse eggs were absent in $H$ pugilinus although reported in several other gastropods with intra capsular development (Natarajan, 1957; Jagadis et al., 2012).

\subsection{Hatching of egg capsules}

$V$ cochlidium laid eggs at intervals of 30-32 days. In this study, only two females laid eggs and it is possible that polygamy exists in this species as has been reported in $B$ undulatum (Markel et al., 1986; Walker, 2007) and Neptunia artritica (Miranda, 2003). This behavior in $V$ cochlidium could not be confirmed due to insufficient number of mating individuals as was the case in $H$ ternatanus (Tang et al., 2012). Most prosobranch gastropods receive and temporarily store sperm in the bursa copulatrix and seminal receptacle which permits prolonged period of egg laying (Paterson et al., 2001).

In $V$ cochlidium, hatching occurred on the $30^{\text {th }}$ day at $28-30^{\circ} \mathrm{C}$ and hatching period extended to 34-35 days at higher temperature. In $H$ ternatanus and $H$ tuba the hatching temperatures ranged from $21-26^{\circ} \mathrm{C}$ (Tang et al., 2012, Morton, 1986a, 1987). Such dependence of hatching on ambient temperature has been reported in several other prosobranchs (Hawkins and Hutchinson, 1988; Sullivan and Maugel, 1984). Xu et al. (2006) reported that $H$ ternatanus eggs hatch in 40-45 days at $25^{\circ} \mathrm{C}$ while $H$ tuba eggs hatch in 30 days at $29^{\circ} \mathrm{C}$ and in 40 days at $23^{\circ} \mathrm{C}$ (Lu et al., 2009). In $V$ cochlidium, it was observed that hatchlings had smaller initial size and lower survival rates at higher temperatures, which has been reported in $H$ tuba also (Tang et al., 2012). This clearly indicates that appropriate incubation temperature is important to optimize survival rates of hatchlings in artificial breeding and juvenile production.

The mean shell length of newly hatched $V$ cochlidium was much smaller $(1.36 \mathrm{~mm})$ than that reported for $H$ ternatanus by Amio (1963), Hamada (1974) and Tang et al., (2012) at $7 \mathrm{~mm}, 6 \mathrm{~mm}$ and 3.42-8.04 mm respectively.

\subsection{Feed preference and growth of hatchlings}

The feed experiment demonstrated that $V$ cochlidium hatchlings are active feeders and consume all types of meat post hatching. However, in $H$ ternatanus no feeding was observed 4-5 days post hatching (Tang et al., 2012).

In the 62- day feeding experiment, the different diets were found to have a significant effect on growth and survival of the juveniles. Mussel meat was the most favored feed followed by clam meat. The specific growth rate in terms of shell length and shell width was highest for the hatchlings fed on mussel meat followed clam meat and least for oyster meat. Feeding oyster meat to the hatchlings resulted in higher mortality due to the fact that the meat putrefied faster leading to deterioration of water quality and thereby mortally of hatchlings. Hatchlings of $H$ ternatanus, in a 10- week experiment exhibited preference for clam 
meat, higher growth rate and lower cumulative mortality (Tang et al., 2012). The higher protein and umami amino acids and the unique flavor account for the dietary preference of $V$ cochlidium and other whelks to bivalves (Morton, 1987; Guterrres and Gallando, 1999; Pehardo and Morton, 2006; He and Yang, 2005; Weng and Sun, 2007; Tang et al., 2012). Similar reports in other whelk species are by Woodcock and Ben Kendorff, 2008; Miranda et al., 2009).

In $V$ cochlidium, acceptance and growth was higher when fed with shrimp meat than fish meat, although protein and amino acid content is higher in fish compared to clams and mussel meat. Higher mortality has been reported in $H$ ternatanus and $N$ arthritica also (Miranda et al., 2009; Tang et al., 2012). However in Babylonia spirata, higher preference for fish (carangid fish) to green mussel has been reported (Kritsanapuntu, et al., 2007). This variation in food preference among whelks can be attributed to the availability of particular food items in their environment. $V$ cochlidium feeds on live as well as dead bivalves (mussels, clams, and oysters), other gastropods and small dead fish present in their habitat. Since bivalves can be preyed upon more easily than on fish, the whelk exhibits a greater preference for bivalves. This could be a significant in the rearing / culture of $V$ cochlidium, since feed cost would be significantly lower.

The juveniles of $V$ cochlidium survived without food during the experimental period of 62 days. $H$ tuba has been reported to survive without food for 39 weeks (Morton, 1986a). $H$ ternatanus also has strong tolerance to starvation (Tang et al., 2012). This may be due to direct absorption of dissolved organic matter (Morton, 1986 a) and / or cannibalism (Lu et al., 2009; Morton, 1987).

$V$ cochlidium is extensively exploited for the shell which has high ornamental value. Therefore, there is danger of over exploitation of the wild stock. $V$ cochlidium is easy to domesticate, larval development is short and direct; the juveniles have fast growth rate and readily accept a wide range of feed. The species is therefore an ideal candidate for culture. The production of juveniles in captive conditions is easy and could aid in the enhancement of wild stock through stock enhancement programs. The whelk $V$ cochlidium, thus has high prospects for mariculture.
References

Anandakumar S., Amutharani G., Gladys Chandraleela A., and Pragatheswaran V., 1986, Biochemical studies on a little known marine gastropod Hemifusus pugilinus Born (Volemidae), Journal of the Marine Biological Association of India, 28:1-2

Chaitanawisuti N., Kritsanapuntu A., 1997, Laboratory spawning and juvenile rearing of the marine gastropod: spotted babylon, Babylonia areolata Link, 1807, (Neogastropoda: Buccinidae), in Thailand, Journal of Shellfish Research, 16: 31-37

Collin R., 2003, Worldwide patterns in mode of development in calyptraeid gastropods, Marine Ecology Progress Series, 247: 103-122 http://dx.doi.org/10.3354/meps247103

Gallardo C.S., Penchaszadeh P.E., 2001, Hatching mode and latitude in marine gastropods: revisiting Thorson's paradigm in the southern hemisphere, Marine Biology, 138: 547-552 http://dx.doi.org/10.1007/s002270000477

Gutiérrez R.M., and Gallardo C.S., 1999, Prey attack, food preference and growth in juveniles of the edible muricid snail, Chorus giganteus, Aquaculture, 174: 69-79 http://dx.doi.org/10.1016/S0044-8486(98)00497-9

Hamada S., 1974, Growth and feeding of Hemifusus ternatanus in early crawling stage, Venus Kyoto (Japanese Journal of Malacology), 33: 75-79 (in Japanese with English abstract)

Hawkins L.E., and Hutchinson S., 1988, Egg capsule structure and hatching mechanism of Ocenebra erinacea (L.) (Prosobranchia: Muricidae), Journal of Experimental Marine Biology and Ecology, 119: 269-283 http://dx.doi.org/10.1016/0022-0981(88)90197-9

Jagadis I., Shanmughasundaram K., and Padmanthan J., 2012, Observations on brood stock maintenance, breeding and early larval development of the common spider conch Lambis lambis (Linnaeus, 1758) in captivity, Indian Journal of Fisheries, 59(2): 165-169

Jagadis I., Shunmugasundaram K., Sathakkathulla M., and Mohanraj T., 2013, Spawning, intracapsular development and production potential of viable juveniles of a murex Chicoreus virgineus var. ponderosa Sowerby under laboratory conditions, Agricultural Sciences, 4: 244-248 http://dx.doi.org/10.4236/as.2013.45035

Kaviarasan T., Siva Sankar R., and Yogamurthi A., 2011, Studies in ultra structure of egg capsule walls of snails using scanning electron microscope, Journal of Coastal Environment, 2 (2): 143-150

Kira T., 1962, Shells of the Western Pacific in color, Hoikusha, Osaka, 224: 72

Kritsanapuntu S., Chaitanawisuti N., Natsukari Y., 2007, Effects of different diets and seawater systems on egg production and quality of the broodstock Babylonia areolata L. under hatchery conditions, Aquaculture Research, 38: 1311-1316 http://dx.doi.org/10.1111/j.1365-2109.2007.01805.x

Lu Z.R., Jiang X.M., Duan X.M., Wang C.L., 2009, Effects of temperature, sediment and food on hatching and growth of juvenile, young Hemifusus tuba, South China Fisheries Science 5: 10-14 (in Chinese with English Abstract)

Martel A., Larrivée D.H., Himmelman J.H., 1986, Behaviour and timing of copulation and egg-laying in the neogastropod Buccinum undatum $\mathrm{L}$, Journal of Experimental Marine Biology and Ecology, 96: 27-42 http://dx.doi.org/10.1016/0022-0981(86)90011-0

Miranda R.M., 2008, Copulation behaviour of Neptunea arthritica: baseline considerations on broodstocks as the first step for seed production technology development, Aquaculture Research, 39: 283-290 http://dx.doi.org/10.1111/j.1365-2109.2008.01901.x

Miranda R.M., Oba T., Goshima S., 2009, Effect of water temperature and diet on growth and mortality of Neptunea arthritica juveniles, Aquaculture Research, 40: 428-436 http://dx.doi.org/10.1111/j.1365-2109.2008.02111.x

Morton B., 1986a, Reproduction, juvenile growth, consumption and the effects of starvation upon the South China Sea whelk Hemifusus tuba (Gmelin) (Prosobranchia: Melongenidae), Journal of Experimental Marine Biology and Ecology, 102: 257-280 http://dx.doi.org/10.1016/0022-0981(86)90181-4

Morton B., 1986b, Prey preference and capture by Hemifusus ternatanus 


\section{International Journal of Aquaculture, 2015, Vol.5, No.19 1-8}

(Gastropoda: Melongenidae), Malacological Review, 19: 107-110

Morton B., 1987, Juvenile growth of the South China Sea whelk Hemifusus tuba (Gmelin) (Prosobranchia: Melongenidae) and the importance of sibling cannibalism in estimates of consumption, Journal of Experimental Marine Biology and Ecology, 109: 1-14 http://dx.doi.org/10.1016/0022-0981(87)90181-X

Narasimham K.A., Selvaraj G.S.D., and Lalitha Devi S., 1984, Marine Fisheries Information Service, Technical and Extension Series, 59: $1-16$

Natarajan A.V., 1957, Studies on the egg masses and larval development of some prosobranchs from the Gulf of Mannar and the Palk Bay Proceedings of the Indian Academy of Sciences, 46b: 70-228

Nasution S., and Roberts D., 2004, Laboratory trials on the effects of different diets on growth and survival of the common whelk, Buccinum undatum L. ,1758, as a candidate species for aquaculture, Aquaculture International, 12: 509-521 http://dx.doi.org/10.1007/s10499-004-5745-7 http://dx.doi.org/10.1007/s10499-005-5745-2

Nugranad J., Kerdpoom N., 1995, Innovative seafood production: mariculture of juvenile Muricid snail Chicoreus ramosus Phuket, Marine Biological Center Special Publication, 15: 55-57

Paterson I.G., Partridge V., Buckland-Nicks J.B., 2001, Multiple paternity in Littorina obtusata (Gastropoda, Littorinidae) revealed by microsatellite analysis, Biology Bulletin, 200: 261-267 http://dx.doi.org/10.2307/1543508

Pechenik J.A., Chang S.C., and Lord A., 1984, Encapsulated development of the marine prosobranch gastropod Nucella lapillus, Marine Biology, 78: 223-229

http://dx.doi.org/10.1007/BF00394705
Peharda M., and Morton B., 2006, Experimental prey species preferences of Hexaplex trunculus (Gastropoda: Muricidae) and predator-prey interactions with the Black mussel Mytilus galloprovincialis (Bivalvia: Mytilidae), Marine Biology, 148: 1011-1019 http://dx.doi.org/10.1007/s00227-005-0148-5

Sekar V., Ravi V., Dhinakaran A., Rajasekaran R., and Ilayaraja C., 2012, Nutritive profiles in different size groups and body parts of common whelk Hemifusus pugilinus (Born, 1778) from Pazhayar, southeast coast of India, Online Journal of Animal Feed Research, 2(2): 189-196

Shanmugam A., Bhuvaneswari T., Arumugam M., Nazeer R.A., and Sambasivam S., 2006, Tissue chemistry of Babylonia spirata (Linnaeus), Indian Journal of Fisheries, 53(1): 33-39

Sundaram K.S., 1974, Edible Gastropods, In: The commercial molluscs of India, CMFRI Bulletin 25, Cochin

Walker D and Power A.J., 2007, Multiple paternity and female sperm usage along egg-case strings of the knobbed whelk, Busycon carica (Mollusca; Melongenidae), Marine Biology 151: 53-61 http://dx.doi.org/10.1007/s00227-006-0463-5

Weng S.B., Sun H.L., 2007, Marine unani substances and characteristic tastes of seafood. China Condiment 11: 21-26 (in Chinese with English abstract)

Wilson B.R., 1985, Direct development in Southern Australian cowries (Gastropoda: Cypraeidae), Australian Journal of Marine and Freshwater Research, 36 (2): 267-280 http://dx.doi.org/10.1071/MF9850267

Woodcock S.H., and Benkendorff K., 2008, The impact of diet on the growth and proximate composition of juvenile whelks, Dicathais orbita (Gastropoda:Mollusca), Aquaculture, 276: 162-170 http://dx.doi.org/10.1016/j.aquaculture.2008.01.036 